\title{
Supply Uncertainty in Food Processing Supply Chain: Sources and Coping Strategies
}

\author{
Atanu Chaudhuri ${ }^{1}$, Iskra Dukovska-Popovska ${ }^{2}$, \\ Cecilie Maria Damgaard ${ }^{2}$, and Hans-Henrik Hvolby ${ }^{2}$ \\ ${ }^{1}$ Department of Business and Management, Aalborg University, Copenhagen, Denmark \\ atanu@business. aau. dk \\ ${ }^{2}$ Centre for Logistics, Department of Mechanical and Manufacturing Engineering, \\ Aalborg University, Aalborg, Denmark \\ iskra@m-tech.aau.dk, cma@mcelog.dk, HHH@m-tech.aau.dk
}

\begin{abstract}
Supply uncertainty aspects haven't been treated specifically in the food processing supply chain management literature, as the focus was mainly on the demand aspects. This paper provides an initial survey on the existing literature dealing with supply uncertainty of food processors. Specifically, the focus is on the types of supply uncertainty and sources that are causing them, as well as how the food processing companies are coping with it in the food supply chain.
\end{abstract}

Keywords. Supply Uncertainty, Food Industry, Coping Strategies.

\section{Introduction}

Most of the food industry is characterized by uncertainty in the supply of raw materials $[1,2]$. In addition, some food producers, because of contracts with suppliers, are obliged to buy the supply of raw material, independently of quantity, quality, and in some cases even the type of specific product [2]. Adequate and timely supply is a pre-requisite for producers' and suppliers' value creation, making it possible for producers to reach their service level targets and allowing the supplier to stay in business.

In many industries supply is considered important, but unproblematic because of predictability and possibility of keeping inventory [1]. However, this is not always the case for food products, where the effects of the environment and long supply lead times affect the predictability of the volume and the quality of the supply. In the literature, uncertainties in supply and demand are recognized to have major impact on the manufacturing function [3]. However, focus of the existing literature has been mostly on balancing demand and supply through creating a demand driven system [4]. This can be challenging when a part of the supply chain (SC) is supply driven [2] and the market price is often influenced by fluctuations in supply [5].

On analyzing the frameworks dealing with supply-demand uncertainty, we realize that the types of uncertainties and uncertainty reduction strategies described may not be entirely relevant for food industry. Lee [6] expands Fisher's framework for linking 
demand uncertainty with SC strategy, to include supply uncertainty. The general strategy he proposes for situations of uncertain supply is risk-hedging through inventory pools or developing multiple supply bases. Van der Vorst and Beulens [3] identify sources of uncertainty and propose SC redesign strategies for food industry, however they do not look in detail for the supply aspects. The contribution in [2] is one of the few which draws attention to the supply driven chains. However, the focus is to explain the concept of supply driven chains and not necessarily to analyze specific supply uncertainties faced by food processing companies.

Thus, we can conclude that there is limited research on how food processing companies can develop appropriate strategies to address the supply uncertainty. Hence, the objectives of this paper are based on literature: first, to identify the supply related characteristics and their related uncertainties faced by food processing companies, and second, to identify the various coping strategies used by the food processing companies in order to deal with the supply uncertainties.

\section{Supply Uncertainties in Food Processing Supply Chains}

Uncertainty can be defined as a situation in which decision makers do not know for sure what will happen and therefore cannot accurately predict external changes [6-8]. This will become more critical if there is a high complexity in the environment (higher number and dissimilarity of the external elements) as well as high instability (the elements shift abruptly) [6, 7]. One of the latest characterizations of food supply chains [9] considers supply uncertainty to be mainly a result of seasonality, demand amplification and economy of scale thinking, and otherwise highly reliable. But, other sources of supply uncertainty do exist in food supply chains (FSCs). Based on FSC case studies, van der Vorst and Beulens [3] identify the following supply-related decision making uncertainties: supply quantity, supply quality and supplier lead time. From the SC risk management literature $[8,10]$ supply cost (price) appears as relevant uncertainty. In addition, size (weight) of the product is uncertainty in the fish and meat industry, while type of the product is a typical uncertainty for the fish industry.

In order to deal with uncertainty one needs to understand the sources leading to it. van der Vorst and Beulens [3] categorize the sources of SC uncertainty as: inherent, chain related, and exogenous. In addition, SC risk literature identifies number of supplier related sources of uncertainty. Below we elaborate on each of these characteristics and how they relate to supply uncertainty. Even though exogenous factors such as governmental regulations affect the supply aspects, these will not be considered in this paper.

Inherent characteristics are "built in" the nature of the supplied product and process, such as: perishability of the raw material, seasonal/variable harvest, being influenced by weather and environment conditions, product's nature of having variable size, and the inverted BOM structure (single raw material consisting of coproducts with different demand). Product perishability creates uncertainty for the buyer with respect to product quality and quantity. When there are distinguishable 
variations in quality among products, food processors face uncertainty in finding sufficient quantity of the product [11]. Seasonal availability and weather conditions are leading to variability. For fishing industry, wild catch volume of different species of fish varies from year to year and also for the same months in different years [1], [12].

Chain related characteristics have been divided into: configuration, control structure, chain information system, and organization and governance.

- Chain configuration relates to the location and the number of the suppliers. Having international suppliers may on one hand decrease quantity uncertainty, but on the other increase supply lead time and quality uncertainty. The distance of supply sources to the producer, can enhance perishability while in transit for fresh produce and may induce stress to chicken or pig and thus influence quality of the meat. For fish procured from fish farms, disease and quality problems are common [12].

- SC control structure relates to information and decision process lead time, supply/ distribution lead time, and coordination of logistic decisions and processes. This may affect the supply lead time and pricing uncertainty as a centrally controlled SC or a cooperative with pricing responsibility may limit pricing uncertainty.-

- SC information system relates to data timeliness, accuracy and data definition, and can have positive impact on decreasing all the uncertainties. However, information secrecy is typical for supply driven chains [2] since if supplier has difficulty selling its products this information can create dampening of the price by the food processor. This can create price uncertainty.

- SC organization and governance structure is related to division of responsibilities, and in relation to the supply can be seen through the commitment, and contracts that exist between the supplier and the processor. Longer-term commitments and contracts can on one hand secure needed quantity and quality, but on the other create unnecessary supply.

Supplier related characteristics encompass internal supplier processes and organization: supplier capacity constraints [13] and uncertain supply capacity [14], supplier quality failure due to failing to maintain capital equipment, lack of supplier training in quality principles and techniques, and damage that occurs in transit [13, 15], business risk when the supplier faces financial problems and may not be in business for long $[13,15]$, risks due to inability of suppliers to stay abreast of technological changes which may have a negative impact on costs, competitiveness of products in the market, and lead-times [13]. In contrary to other industries where supplier high capacity utilization is considered as a source of risk [15], for a supply driven chains, which is a characteristic of the upstream part of the FSCs, high capacity utilization may be desirable as production below optimal or full capacity may not be economically viable and can result in possible reverse bullwhip effect [2].

Further on we identify, based on literature, how the uncertainties are characterized at four fresh food industries (Table 1). 
Table 1. Characteristics of supply uncertainties in food processing supply chain

\begin{tabular}{|c|c|c|c|c|}
\hline & Fish processor & Dairy & Meat processor & $\begin{array}{l}\text { Fruits and vegetables } \\
\text { processor }\end{array}$ \\
\hline $\begin{array}{l}\text { Supply } \\
\text { quantity }\end{array}$ & $\begin{array}{l}\text { High uncertainty } \\
\text { [16], High catch } \\
\text { variety from year to } \\
\text { year and for the } \\
\text { same month for } \\
\text { different years } \\
\text { [12],some parts of } \\
\text { the fish have higher } \\
\text { demand than others. }\end{array}$ & $\begin{array}{l}\text { High uncertain- } \\
\text { ty until delivery } \\
\text { [17], weather } \\
\text { induced varia- } \\
\text { bility [18], } \\
\text { whey, generated } \\
\text { with cheese, has } \\
\text { low margin [2] }\end{array}$ & $\begin{array}{l}\text { Variation in individual } \\
\text { bird weights which can } \\
\text { result in varying pro- } \\
\text { portions of heavier and } \\
\text { lighter birds [19], some } \\
\text { parts of the chicken } \\
\text { have higher demand } \\
\text { then others [2] }\end{array}$ & $\begin{array}{l}\text { Crop yield uncertainty due } \\
\text { to weather conditions, } \\
\text { contagious bacterial diseas- } \\
\text { es [20], fresh produce } \\
\text { heavily exposed to envi- } \\
\text { ronment [21] }\end{array}$ \\
\hline $\begin{array}{l}\text { Supply } \\
\text { quality, } \\
\text { product size } \\
\text { and type }\end{array}$ & $\begin{array}{l}\text { Uncertainty depend- } \\
\text { ing on periods and } \\
\text { biology[1,16, 22], } \\
\text { Temperature sensi- } \\
\text { tive [16], quality } \\
\text { degradation de- } \\
\text { pends on microbial } \\
\text { growth [22] }\end{array}$ & $\begin{array}{l}\text { High contami- } \\
\text { nation risk [23] }\end{array}$ & $\begin{array}{l}\text { High and variable } \\
\text { mortality, weight or fat } \\
\text { variability, poor lairage } \\
\text { control at abattoir } \\
\text { affecting pig quality } \\
\text { [24], variable quality of } \\
\text { beasts and microbial } \\
\text { growth [22, 25] } \\
\end{array}$ & $\begin{array}{l}\text { High uncertainty from } \\
\text { environment (air, soil, } \\
\text { water, insects, rodents, etc.) } \\
\text { and manual manipulation } \\
\text { and thus intrinsically } \\
\text { potentially heavily conta- } \\
\text { minated }[21,26]\end{array}$ \\
\hline $\begin{array}{l}\text { Supply lead } \\
\text { time }\end{array}$ & $\begin{array}{l}\text { High uncertainty, } \\
\text { between } 4 \text { to } 13 \\
\text { weeks [12] }\end{array}$ & $\begin{array}{l}\text { Low uncertain- } \\
\text { ty, daily deli- } \\
\text { very }[27,28]\end{array}$ & $24-30$ months $[24,25]$ & $\begin{array}{l}\text { Reach their peak value at } \\
\text { the time of harvest; product } \\
\text { value deteriorating expo- } \\
\text { nentially post-harvest until } \\
\text { the product is cooled to } \\
\text { dampen the } \\
\text { deterioration [27] }\end{array}$ \\
\hline Supply Price & $\begin{array}{l}\text { Total cost uncer- } \\
\text { tainty from having } \\
\text { to buy all from } \\
\text { fishermen }[2,16]\end{array}$ & $\begin{array}{l}\text { High variation } \\
\text { in price }[5,28], \\
\text { Total cost } \\
\text { uncertainty }[17, \\
18]\end{array}$ & $\begin{array}{l}\text { Mix of auction (rather } \\
\text { variable price) and } \\
\text { deadweight procure- } \\
\text { ment (rather fixed } \\
\text { price) for beef [29] }\end{array}$ & $\begin{array}{l}\text { Total cost uncertainty from } \\
\text { having to buy all output of } \\
\text { fruits and vegetables [2] }\end{array}$ \\
\hline
\end{tabular}

\section{$3 \quad$ Coping Strategies}

We specifically analyze literature addressing supply uncertainties in processing fish, meat, dairy, and fruits and vegetables to identify coping strategies. We aim to identify and relate coping strategies with the sources of uncertainty.

Coping strategies at fish industry. Some of the coping strategies address the uncertainties related to the inherent characteristics of the supply. These include: farming and thus controlling the type and size of raw products at the supplier [5]; optimizing the product mix [1], flexible product mix planning [5], sorting and grading [5] at the processor to ensure quality and maximize margins while considering the variable demand of different co-products. Other strategies deal with the SC related sources of uncertainty. Backward integration by owning a stake in fishing vessels to signal commitment and ensure availability of supply [30] is a SC organization aspect. Maintaining a portfolio of suppliers and focusing on specific types of vessels to get the desired catch are SC configuration related coping strategies [30], which can be used to reduce uncertainties of volume and quality, reduce supplier related uncertainty of capacity constraints faced by individual suppliers due to quota restrictions or limited number of vessels or manpower and also to reduce supplier opportunism. Another strategy is catch-based aquaculture [1] where a fish is caught in periods when it is close to shore and easy to catch, then kept alive, and fed to better serve the market demand for fresh fish. This coping strategy addresses the inherent uncertainty by decreasing the influence of the seasonal variations. It also deals with SC control 
related uncertainty as it enables better coordination between processor needs and the supply. It may be considered similar to having a raw material or semi-finished inventory buffer to match supply with demand but can result in additional costs and is time consuming [1]. In addition, it addresses supplier capacity characteristics by reducing its uncertainty. Finally, we identified some coping strategies that deal with supplier related sources of uncertainty. Processors could offer various services to the fishing vessels to make themselves attractive, motivate the staff to stay extra time onboard by paying the crew a fixed portion of the sales revenue [1], offer good prices to attract and educate specific suppliers [30], while suppliers could exercise volume flexibility by varying the length of time at sea to catch the allotted quotas.

Coping strategies at meat industry. Many coping strategies focus on reducing the inherent sources that are causing quality uncertainties. Such strategies include: environmental control in broiler houses, reducing pre-slaughter stress, care in handling and transportation [31] at the supplier; quality assurance schemes [29], and automated carcass identification system to enable traceability [32] at the processor. Other strategies deal with the inherent sources leading to quantity uncertainties and involve: quick and efficient rerouting of low demand co-produce to different markets, and optimal planning and scheduling of various end products [19]. A number of strategies have been identified that deal with $S C$ related sources of uncertainty: collaboration between farmer co-operatives, processor and retailer to strengthen links with farmers thereby ensuring consistency and improved quality [8], and selecting firms to minimize transport distances to the abattoir [24] thereby reducing transportation lead time. Another SC organization/governance aspect is related to a common price set by cooperative system based on objective measurement of carcass grade [32] which reduces pricing uncertainty.

Coping strategies at dairy industry. Some of the strategies that cope with inherent characteristics of the raw material include: keeping the milk at the right temperature [33], storing larger unused amounts of fat from the milk, or processing into milk powder when excess supply amounts appear [9], efficient vehicle routing. From a $S C$ organization and governance perspective, long-term partnerships and contracts are typical for dairy industry[23, 34], as well as efficient management of the cooperatives. Incentivizing them to improve yield as well as on-time payments to ensure regular supply is used as a supplier related strategy [23]. SC configuration strategies include buying and collecting milk within certain kilometers of distance and from a larger amount of farmers, thus ensuring needed quantity.

Coping strategies at fruits and vegetables industry. Inherent sources of uncertainties related to perishability can be managed by efficient temperature controlled logistics to reduce supply quality variations [35], by substituting fresh products with frozen products wherever possible, and optimal product mix planning. Blackburn and Scudder [27] propose designing a hybrid of a responsive SC from post-harvest to cooling, followed by an efficient one in the remainder of the chain. The authors demonstrate that these two segments of the SC are only loosely linked, implying that little coordination is required across the chain to achieve value maximization. Thus, it also obviates some chain related uncertainties due to lack of co-ordination and information sharing. Supply chain related strategies include: having multiple suppliers, classifying suppliers to take care of variable quality [35], using spot-markets [36], profit sharing 
based on quality parameters to ensure quality and foster collaboration [37], using revenue sharing contract to coordinate a two stage agri-supply chain by selecting suitable wholesale price and revenue sharing percentage [38], using inventory policies with re-order point model under supply uncertainty [39]. Supplier related strategies include quality based pricing which can result in improvement in quality and on-time delivery of quality fruits [40]. Fig. 1 summarizes the different coping strategies.

Coping strategies for inherent
characteristics of the supply
- Control of type and size at the supplier
- Optimizing product mix
- Flexible product mix planning
- Sorting and grading products
- Environmental/temperature control
- Reducing pre-slaughter stress
- Care in handling and transportation
- Quality assurance schemes
- Automated carcass identification system
- Rerouting of low demand co-produce
- Planning of various end product
- Storing unused part of co-product
- Processing into less perishable products
- Efficient vehicle routing
- Substituting fresh with frozen products
- Hybrid supply chain design

Coping strategies for supply chain related
sources of uncertainty
- Backward integration
- Maintaining a portfolio of suppliers
- Focusing on specific types of fishing
vessels
- Catch-based aquaculture
- Collaboration in supply chain
- Selecting firms to minimize transport
- Set price by co-operative system
- Long-term partnerships and contracts
- Management of the co-operatives
- Having multiple suppliers
- Classifying suppliers
- Using spot-markets
- Using profit sharing based on quality
- Using revenue sharing contract
- Using inventory policies

Coping strategies for supplier related
sources of uncertainty
- Offer more services
- Motivate the staff and suppliers
- Offer good prices
- Educate specific suppliers
- Varying capacity constrains
- On-time payments
- Quality based pricing

Fig. 1. Overview of the different coping strategies

The fish processing industry is practicing strategies dealing with all three types of sources of uncertainties. Some of the strategies are focusing on reducing the uncertainties (quantity and type/size) through various risk hedging mechanisms (farming, SC configuration), while other focus on dealing with the uncertainties (volume and product mix flexibility). The meat processing industry seems to focus more on the inherent and SC related sources. Reducing uncertainty is done through supplier quality improvement, lead time reduction, and common/transparent pricing, while dealing with uncertainty is through product mix planning. Dairy industry focuses primarily on reducing inherent related uncertainties of quality (environment and transport control) and of quantity (partnerships and contracts), as well as supplier related uncertainties (incentivizing suppliers). Fresh produce industry focuses on reducing inherent uncertainties because of perishability (temperature control) and dealing with it (hybrid SC design), as well as dealing with supply chain related uncertainty. Design of contracts to deal with pricing uncertainty has emerged as a separate field of literature.

Looking across industries, all involve strategies that reduce and deal with the inherent sources of uncertainty. From the strategies coping with SC related sources, SC configuration is considered in all the industries, followed by SC organization (in all except fresh produce). SC control appeared only in fish industry, while SC cooperation in the meat industry. Supplier related strategies were evident in all industries besides meat.

\section{Conclusion}

This paper characterizes the supply uncertainties of the food processors in terms of supply quantity, quality, lead time and price, and links them to the sources of 
such uncertainties which are broadly classified as inherent, chain related and supplier related. This characterization also helps in analyzing the different coping strategies adopted by fish, meat, dairy and fresh produce processors. Few gaps emerge from our analysis of the characterization and the coping strategies.

While all food processing industries do get impacted by the configuration of suppliers and their control structure, there is limited research on deciding the appropriate network structure for example the number and type of suppliers and the kind of engagement with them. In addition, we didn't observe any SC information sharing mechanisms passing on the information, for example about the type and quality of raw material. This is surprising, since information sharing is a main strategy for reducing uncertainty. There is a need to analyze supply patterns, quality and prices, and develop analytical solutions or decision support to determine the appropriate network structure and contracting mechanisms with the objective of maximizing profit for appropriate quality constraints. There are also possibilities to develop combined sourcing and product mix planning decisions and to empirically determine the impact of sourcing uncertainty reduction strategies on the performance of the firms.

Acknowledgement. This paper is possible because of the LogiNord project funded by NordForsk.

\section{References}

1. Dreyer, B., Grønhaug, K.: Coping with unpredictable supply: the role of flexibility and adaptation. European Journal of Marketing 46, 1268-1282 (2012)

2. Hull, B.Z.: Are supply (driven) chains forgotten? The International Journal of Logistics Management 16, 218-236 (2005)

3. Van der Vorst, J.G.A.J., Beulens, A.J.M.: Identifying sources of uncertainty to generate supply chain redesign strategies. International Journal of Physical Distribution \& Logistics Management 32, 409-430 (2002)

4. Van der Vorst, J., van Dijk, S.J., Beulens, A.J.M.: Supply Chain Design in the Food Industry. TheInternational Journal of Logistics Management 12, 73-86 (2001)

5. Ottesen, G.G., Grønhaug, K.: Market orientation and uncertain supply in upstream markets: an exploratory study. European Journal of Purchasing \& Supply Management 8, 209-219 (2002)

6. Lee, H.L.: Aligning Supply Chain Strategies with Product Uncertainties. California management review 44 (2002)

7. Daft, R.L., Murphy, J., Willmott, H.: Organization Theory and Design. CENGAGE Lrng Business Press, Mason (2010)

8. Leat, P., Revoredo-Giha, C.: Risk and resilience in agri-food supply chains: the case of the ASDA PorkLink supply chain in Scotland. Supply Chain Management: An International Journal 18, 219-231 (2013)

9. Romsdal, A.: Differentiated production planning and control in food supply chains. Doctoral theses (2014)

10. Tang, C.S.: A review of marketing-operations interface models: From co-existence to coordination and collaboration. International Journal of Production Economics 125, 22-40 (2010) 
11. Hobbs, J.E., Young, L.M.: Closer vertical co-ordination in agri-food supply chains: a conceptual framework and some preliminary evidence. Supply Chain Management: An International Journal 5, 131-143 (2000)

12. Hameri, A.-P., Pálsson, J.: Supply chain management in the fishing industry: the case of Iceland. International Journal of Logistics Research and Applications 6, 137-149 (2003)

13. Zsidisin, G.A., Panelli, A., Upton, R.: Purchasing organization involvement in risk assessments, contingency plans, and risk management: an exploratory study. Supply Chain Management: An International Journal 5, 187-198 (2000)

14. Tang, C.S.: Perspectives in supply chain risk management. International Journal of Production Economics 103, 451-488 (2006)

15. Tummala, R., Schoenherr, T.: Assessing and managing risks using the Supply Chain Risk Management Process (SCRMP). Supply Chain Management: An International Journal 16, 474-483 (2011)

16. Ivert, L.K., Dukovska-Popovska, I., Kaipia, R., Fredriksson, A., Johansson, M., Dreyer, H., Chabada, L., Damgaard, C.M., Tuomikangas, N.: Sales and operations planning: responding to the needs of industrial food producers 2014 (2014)

17. Hovelaque, V., Duvaleix-Tréguer, S., Cordier, J.: Effects of constrained supply and price contracts on agricultural cooperatives. European Journal of Operational Research 199, 769-780 (2009)

18. Guan, Z., Philpott, A.B.: A multistage stochastic programming model for the New Zealand dairy industry. International Journal of Production Economics 134, 289-299 (2011)

19. Bisht, B., Pandey, S.: Planning Efficiency in perishable food operations (2012)

20. Kazaz, B., Webster, S.: The Impact of Yield-Dependent Trading Costs on Pricing and Production Planning Under Supply Uncertainty. M\&SOM 13, 404-417 (2011)

21. Jacxsens, L., Luning, P.A., van der Vorst, J.G.A.J., Devlieghere, F., Leemans, R., Uyttendaele, M.: Simulation modelling and risk assessment as tools to identify the impact of climate change on microbiological food safety - The case study of fresh produce supply chain. Food Research International 43, 1925-1935 (2010)

22. Rong, A., Akkerman, R., Grunow, M.: An optimization approach for managing fresh food quality throughout the supply chain. International Journal of Production Economics 131, 421-429 (2011)

23. Gorton, M., Dumitrashko, M., White, J.: Overcoming supply chain failure in the agri-food sector: A case study from Moldova. Food Policy 31, 90-103 (2006)

24. Taylor, D.H.: Strategic considerations in the development of lean agri-food supply chains: a case study of the UK pork sector. Supply Chain Management: An International Journal 11, 271-280 (2006)

25. Cox, A., Chicksand, D.: The Limits of Lean Management Thinking: Multiple Retailers and Food and Farming Supply Chains. European Management Journal 23, 648-662 (2005)

26. Chai, L.C., Robin, T., Ragavan, U.M., Gunsalam, J.W., Bakar, F.A., Ghazali, F.M., Radu, S., Kumar, M.P.: Thermophilic Campylobacter spp. in salad vegetables in Malaysia. International Journal of Food Microbiology 117, 106-111 (2007)

27. Blackburn, J., Scudder, G.: Supply Chain Strategies for Perishable Products: The Case of Fresh Produce. Production and Operations Management 18, 129-137 (2009)

28. Romsdal, A., Strandhagen, J.O., Dryer, H.C.: Linking supply chain configuration with production strategy; the case of food production. In: 4th World P\&OM Conference (2012)

29. Fearne, A.: The evolution of partnerships in the meat supply chain: insights from the British beef industry. Supply Chain Management: An International Journal 3, 214-231 (1998) 
30. Ottesen, G.G., Grønhaug, K.: Primary Uncertainty in the Seafood Industry: An Exploratory Study of How Processing Firms Cope. Marine Resource Economics 18, 363-371 (2003)

31. Baracho, M.S., Camargo, G.A., Lima, A.M.C., Mentem, J.F., Moura, D.J., Moreira, J., Nääs, I.A.: Variables impacting poultry meat quality from production to pre-slaughter: a review. Revista Brasileira de Ciência Avícola 8, 201-212 (2006)

32. Hobbs, J.E., Kerr, W.A., Klein, K.K.: Creating international competitiveness through supply chain management: Danish pork. Supply Chain Management: An International Journal 3, 68-78 (1998)

33. Entrup, M.L.: Advanced planning in fresh food industries - integrating shelf life into production planning. Springer (2005)

34. Deimel, M., Frentrup, M., Theuvsen, L.: Transparency in food supply chains: empirical results from German pig and dairy production. Journal on Chain and Network Science 8, 21-32 (2008)

35. Wilson, N.: Supply chain management: a case study of a dedicated supply chain for bananas in the UK grocery market. Supply Chain Management: An International Journal 1, 28-35 (1996)

36. He, Y., Zhao, X.: Coordination in multi-echelon supply chain under supply and demand uncertainty. International Journal of Production Economics 139, 106-115 (2012)

37. Formentini, M., Boscari, S., Romano, P.: Quality Based Pricing and collaborative negotiation in agrifood supply chains. In: Presented at the 20th EUROMA Conference, Dublin (June 2013)

38. Zhao, X., Wu, F.: Coordination of agri-food chain with revenue-sharing contract under stochastic output and stochastic demand. Asia Pac. J. Oper. Res. 28, 487-510 (2011)

39. Yeo, W.M., Yuan, X.-M.: Optimal inventory policy with supply uncertainty and demand cancellation. European Journal of Operational Research 211, 26-34 (2011)

40. Hines, P., Francis, M., Bailey, K.: Quality-based pricing: a catalyst for collaboration and sustainable change in the agrifood industry? International Journal of Logistics Management 17, 240-259 (2006) 